\title{
Synthesis and Photophysical Properties of Novel Highly Stable Zero/Bis-Zero Methine Cyanine Dyes Based on N-Bridgehead Heterocycles
}

\author{
Ahmed I. Koraiem1, Islam M. Abdellah ${ }^{1,2}{ }^{*}$, Ahmed M. El-Shafei ${ }^{2}$ \\ ${ }^{1}$ Department of Chemistry, Faculty of Science, Aswan University, Aswan, Egypt \\ ${ }^{2}$ Polymer and Color Chemistry Program, North Carolina State University, Raleigh, USA \\ Email: *imabdell@ncsu.edu
}

How to cite this paper: Koraiem, A.I., Abdellah, I.M. and El-Shafei, A.M. (2018) Synthesis and Photophysical Properties of Novel Highly Stable Zero/Bis-Zero Methine Cyanine Dyes Based on N-Bridgehead Heterocycles. International Journal of Organic Chemistry, 8, 282-297.

https://doi.org/10.4236/ijoc.2018.83021

Received: May 9, 2018

Accepted: July 31, 2018

Published: August 3, 2018

Copyright $\odot 2018$ by authors and Scientific Research Publishing Inc. This work is licensed under the Creative Commons Attribution International License (CC BY 4.0). http://creativecommons.org/licenses/by/4.0/ Open Access

\begin{abstract}
Cyanine dyes of zero/bis-zero methine incorporating imidazo(1,2-a)Pyridine (quinoline) or pyrazino(1,2-a)pyridine (quinoline) with stable $\mathrm{C}-\mathrm{N}$ bond were synthesized using keto-oxime methylene C-link heterocyclic quaternary salts [1-phenyl-3-methyl-pyrazolino-4-keto-oxime- $\alpha$-methylene-bis-pyridin-(quin oin)-1(4)-di-ium-iodide(ethiodide) salts and 1-phenyl-3-methyl-pyrazolino4-ketooxime- $\alpha$-methylene-N-2-methyl-bis pyridin (quinoin)-1(4)-di-iumiodide(ethiodide) salts]. Such heterocyclic precursors and related dyes were identified by elemental and spectral analyses. The absorption spectra properties of such dyes were investigated in $95 \%$ Ethanol to attempt and throw some light on the influence of such new heterocyclic nuclei and to compare or evaluate spectral behaviors. The absorption spectra of dyes in different pure solvents were examined in the visible region showing solvatochromism and the colour changes of dyes with solvents having different polarities. This permits a selection of the optimal solvent (fractional solvent) when such dyes are applied as photosensitizers. The spectral behavior of some selected newly synthesized cyanine dyes is observed in mixed solvents of different polarities and progressively increasing quantities of one solvent over the other were studied and showed an increase in the absorbance of CT band with increasing proportion of that solvent. Evidence for hydrogen bond formation between the solute molecules and solvent molecules allows measurement of certain energies such as hydrogen bonding, orientation, and free energies.
\end{abstract}

\section{Keywords}

N-Bridgehead Heterocycles, Cyanine Dyes, Zero/Bis-Zero Methine, 
Solvatochromic Behaviours

\section{Introduction}

Special attention is given to the implementation, preparations, and applications of heterocyclic cyanine dyes to show the various aspects in order to satisfy the great demand in industrial, physiology, biochemistry and various biological fields. Cyanine dyes are colorant compounds used in staining of internal limiting membrane (ILM) [1] [2] [3], as fluorescent dyes in DNA detection [4] [5] [6] [7], optical sensors [8] [9], organic photoconductors [10], vulcanizing accelerator agents, photographic sensitizers [11], solar cell [12]. This multi-property and numerous applications of cyanine dyes push the scientist to design and improve synthetic procedure of new cyanine dyes based on N-bridgehead heterocycles [13] [14], which are characterized by outstanding chemical stability, absorb at long wavelength [15] [16], high solubility and change their optical, thermal or electronic properties to meet the requirements for opto-electronic or biological products.

$\mathrm{N}$-Bridgehead heterocyclic cyanine dyes are an important class of dyes which are characterized by the presence of nitrogen atom inside the ring. N-bridge head heterocyclic compounds used as precursors possess high site reactivity susceptible to be attacked by either Electrophile/Nucleophile in the substitution/addition reactions which give high stability nature for the dyes [17]. These dyes have many vital general applications back to their higher stability which can be used as bioactive compounds such as the N-methyl-D aspartate antagonists [18]. Furthermore, N-Bridgehead heterocyclic cyanine dyes have a wide range of potential applications in fluorescent compounds, DNA-binding dyes [19] and organic materials [20]. According to their bioactivity and structural planarity, it is a reasonable idea to develop functional dyes based on these N-Bridgehead heterocycles. A variety of cyanine dyes incorporating different $\mathrm{N}$-bridgehead heterocyclic moieties have been reported [21] [22] [23] [24].

In this paper, we designed and synthesized novel highly stable cyanine dyes. Keto-oxime methylene C-link heterocyclic quaternary salts were used in the synthesis of $\mathrm{N}$-bridge head heterocyclic incorporating imidazolo(1,2-a)pyridine(quinoline) or pyrazino(1,2-a)pyridine(quinoline) as main entities for zero and bis-zero methine cyanine dyes synthesis. The spectral, solvatochromic behavior and mixed solvent effect are described.

\section{Experimental}

\subsection{Physical and Chemical Properties Determinations}

All melting points are uncorrected Elemental and spectral analysis was carried out at the microanalytical center (Cairo University). The IR ( $\nu \mathrm{KBr}$ ) spectra were determined with Perkin Elmer Infrared 127ß spectrophotometer (Cai- 
ro-University). ${ }^{1} \mathrm{H}-\mathrm{NMR}$ spectra were recorded with a Bruker AMX-250 spectrometer (Cairo-University). Mass spectra were recorded on an HpMs 6988 spectrometer (Cairo University). The absorption spectra were recorded immediately after preparation of the solutions within the wavelength range (350 - 700) on 6405 UV/Visible recording spectrophotometers, Faculty of Science, Aswan University.

\subsection{Synthesis}

Analytical data and molecular Properties for all the starting N-bridge head heterocycles and the target dyes involved in this study was obtained and summarized in (Table 1).

Table 1. Characterization data for $(1 ; 2 \mathrm{a}, \mathrm{b} ; 3 \mathrm{a}, \mathrm{b} ; \mathbf{4 a}, \mathrm{b} ; 5 \mathrm{a}, \mathrm{b}$ and $6 \mathrm{a}-\mathrm{f})$.

\begin{tabular}{|c|c|c|c|c|c|c|c|c|c|}
\hline \multirow{2}{*}{$\begin{array}{l}\text { Comp. } \\
\text { No. }\end{array}$} & \multirow{2}{*}{ M.P ${ }^{\circ} \mathrm{C}$} & \multirow{2}{*}{$\begin{array}{l}\text { Yield } \\
\%\end{array}$} & \multirow{2}{*}{ Color } & \multirow{2}{*}{$\begin{array}{l}\text { Mol. Formula } \\
\text { (Mol. Wt.) }\end{array}$} & \multicolumn{3}{|c|}{ Calcd. (Found)\% } & \multicolumn{2}{|c|}{ Absorption spectra in EtOH } \\
\hline & & & & & $\mathrm{C}$ & $\mathrm{H}$ & $\mathrm{N}$ & $\lambda_{\max }(\mathrm{nm})$ & $\varepsilon_{\max }\left(\mathrm{M}^{-1} \mathrm{~cm}^{-1}\right)$ \\
\hline 1 & 125 & 78 & Pale brown & $\begin{array}{c}\mathrm{C}_{23} \mathrm{H}_{24} \mathrm{IN}_{5} \mathrm{O} \\
(513)\end{array}$ & $\begin{array}{l}53.81 \\
53.82\end{array}$ & $\begin{array}{l}4.71 \\
4.70\end{array}$ & $\begin{array}{l}13.64 \\
13.66\end{array}$ & 350 & 1778 \\
\hline $2 a$ & 129 & 60 & Brown & $\begin{array}{c}\mathrm{C}_{28} \mathrm{H}_{28} \mathrm{I}_{2} \mathrm{~N}_{6} \mathrm{O} \\
(718)\end{array}$ & $\begin{array}{l}46.81 \\
46.80\end{array}$ & $\begin{array}{l}3.93 \\
3.95\end{array}$ & $\begin{array}{l}11.70 \\
11.71\end{array}$ & 365 & 1785 \\
\hline $2 b$ & 135 & 58 & Red & $\begin{array}{c}\mathrm{C}_{32} \mathrm{H}_{30} \mathrm{I}_{2} \mathrm{~N}_{6} \mathrm{O} \\
(768)\end{array}$ & $\begin{array}{l}50.02 \\
50.09\end{array}$ & $\begin{array}{l}3.94 \\
3.94\end{array}$ & $\begin{array}{l}10.94 \\
10.95\end{array}$ & $\begin{array}{l}365 \\
440\end{array}$ & 1795,797 \\
\hline $3 a$ & 140 & 75 & Dark red & $\begin{array}{c}\mathrm{C}_{29} \mathrm{H}_{30} \mathrm{I}_{2} \mathrm{~N}_{6} \mathrm{O} \\
(732)\end{array}$ & $\begin{array}{l}47.56 \\
47.54\end{array}$ & $\begin{array}{l}4.13 \\
4.14\end{array}$ & $\begin{array}{l}11.47 \\
11.48\end{array}$ & $\begin{array}{l}365 \\
490\end{array}$ & 1667,923 \\
\hline $3 b$ & 145 & 82 & Brown & $\begin{array}{c}\mathrm{C}_{19} \mathrm{H}_{16} \mathrm{~N}_{6} \mathrm{O}_{2} \\
(360)\end{array}$ & $\begin{array}{l}63.26 \\
63.29\end{array}$ & $\begin{array}{l}4.43 \\
4.47\end{array}$ & $\begin{array}{l}23.30 \\
23.32\end{array}$ & $\begin{array}{l}365 \\
495\end{array}$ & 1789,1100 \\
\hline $4 a$ & 165 & 71 & Brown & $\begin{array}{c}\mathrm{C}_{28} \mathrm{H}_{25} \mathrm{IN}_{6} \\
(572)\end{array}$ & $\begin{array}{l}58.75 \\
58.73\end{array}$ & $\begin{array}{l}4.40 \\
4.41\end{array}$ & $\begin{array}{l}14.68 \\
14.69\end{array}$ & 470 & 1092 \\
\hline $4 \mathrm{~b}$ & 190 & 66 & Brown & $\begin{array}{c}\mathrm{C}_{32} \mathrm{H}_{27} \mathrm{IN}_{6} \\
(622)\end{array}$ & $\begin{array}{l}61.74 \\
61.76\end{array}$ & $\begin{array}{l}4.37 \\
4.35\end{array}$ & $\begin{array}{l}13.50 \\
13.52\end{array}$ & 485 & 1397 \\
\hline $5 a$ & 127 & 61 & Red & $\begin{array}{c}\mathrm{C}_{21} \mathrm{H}_{18} \mathrm{~N}_{6} \mathrm{O}_{3} \mathrm{~S} \\
(434)\end{array}$ & $\begin{array}{l}58.00 \\
58.09\end{array}$ & $\begin{array}{l}4.14 \\
4.15\end{array}$ & $\begin{array}{l}19.33 \\
19.30\end{array}$ & 460 & 698 \\
\hline $5 b$ & 170 & 65 & Reddish & $\begin{array}{c}\mathrm{C}_{21} \mathrm{H}_{18} \mathrm{ClN}_{5} \mathrm{OS} \\
(423)\end{array}$ & $\begin{array}{l}59.446 \\
59.445\end{array}$ & $\begin{array}{l}4.24 \\
4.27\end{array}$ & $\begin{array}{l}16.51 \\
16.55\end{array}$ & 498 & 1010 \\
\hline $6 a$ & 155 & 74 & Red & $\begin{array}{c}\mathrm{C}_{21} \mathrm{H}_{18} \mathrm{~N}_{6} \mathrm{O}_{3} \mathrm{~S} \\
(434)\end{array}$ & $\begin{array}{l}58.001 \\
58.000\end{array}$ & $\begin{array}{l}4.14 \\
4.13\end{array}$ & $\begin{array}{l}19.33 \\
19.36\end{array}$ & 390,520 & 2700,2443 \\
\hline $6 \mathrm{~b}$ & 150 & 59 & Red & $\begin{array}{c}\mathrm{C}_{40} \mathrm{H}_{37} \mathrm{I}_{2} \mathrm{~N}_{7} \\
\quad(869)\end{array}$ & $\begin{array}{l}55.25 \\
55.25\end{array}$ & $\begin{array}{l}4.29 \\
4.30\end{array}$ & $\begin{array}{l}11.28 \\
11.30\end{array}$ & 480 & 670 \\
\hline $6 c$ & 130 & 59 & Pale brown & $\begin{array}{c}\mathrm{C}_{21} \mathrm{H}_{17} \mathrm{Cl}_{2} \mathrm{~N}_{5} \mathrm{O} \\
(426)\end{array}$ & $\begin{array}{l}59.11 \\
59.10\end{array}$ & $\begin{array}{r}3.987 \\
3.89\end{array}$ & $\begin{array}{c}16.420 \\
16.41\end{array}$ & 500 & 1780 \\
\hline $6 d$ & 185 & 68 & Brown & $\begin{array}{c}\mathrm{C}_{40} \mathrm{H}_{39} \mathrm{I}_{2} \mathrm{~N}_{7} \\
(871)\end{array}$ & $\begin{array}{l}55.12 \\
55.14\end{array}$ & $\begin{array}{c}4.51 \\
4.5\end{array}$ & $\begin{array}{l}11.25 \\
11.23\end{array}$ & 475 & 612 \\
\hline $6 e$ & 185 & 75 & Red & $\begin{array}{c}\mathrm{C}_{44} \mathrm{H}_{39} \mathrm{I}_{2} \mathrm{~N}_{7} \\
(919)\end{array}$ & $\begin{array}{l}57.47 \\
57.45\end{array}$ & $\begin{array}{l}4.27 \\
4.28\end{array}$ & $\begin{array}{l}10.66 \\
10.69\end{array}$ & 478 & 1593 \\
\hline $6 f$ & 160 & 61 & Red & $\begin{array}{c}\mathrm{C}_{44} \mathrm{H}_{39} \mathrm{I}_{2} \mathrm{~N}_{7} \\
(919)\end{array}$ & $\begin{array}{l}57.47 \\
57.48\end{array}$ & $\begin{array}{l}4.27 \\
4.28\end{array}$ & $\begin{array}{l}10.66 \\
10.65\end{array}$ & 474 & 1012 \\
\hline
\end{tabular}


2.2.1. 3-Methyl-1-phenyl-pyrazolin-4,4-ketooxime-methylene-pyridine (quinoline)-1-ium Ethiodide Salt (1)

A mixture of 3-methyl-1-phenyl-pyrazolino-5-imino-4-(N-acetyl-quinolin-1-ium iodide, 1 mole), hydroxylamine hydrochloride (2 moles) and sodium acetate (3 moles) was dissolved in ethanol $(30 \mathrm{ml})$ and heated in a water bath for an hour. The reaction mixtures were filtrated from unreacted materials. The reaction mixture quenched by water and extracted by chloroform $(3 \times 50 \mathrm{ml})$. The combined organic layers were washed with water, dried over $\mathrm{MgSO}_{4}$ and evaporated under reduced pressure. The product was purified via recrystallization from ethanol.

\subsubsection{1-Phenyl-3-methyl-pyrazolin-4-ketooxime- $\alpha$-methylen-bis-pyridine} (quinoline)-4(1)-di-ium-iodide(ethiodide) Salts (2a, b \& 3a, b)

Ethanolic solution of compound 1 ( $1 \mathrm{~mol}$ ) with pyridine (quinoline) or 2 methyl pyridine (2-methyl quinoline) $(1 \mathrm{~mol})$ and iodine $(1 \mathrm{~mol})$. The mixture was stirred and refluxed for 3 - 5 hrs. The reaction mixtures were filtrated from unreacted materials. The filtrate was concentrated to one third of its volume, cooled. The precipitated products after dilution with water were separated, filtrated, recrystallized from diethyl ether.

\subsubsection{Synthesis of 2-[3-Methyl-1-phenyl-pyrazolin-5-imine] imidazo(1,2-a) Pyridine (quinoline)-zero-3 [4(1)] Methine Cyanine Dyes $(4 a, b)$}

Fusion of $2 \mathrm{a}, \mathrm{b}$ with piperidine for about an hour then dissolved the reaction mixture in anhydrous ethanol and reflux for 3 hours. The reaction mixture quenched by water and extracted by methylene chloride $(50 \mathrm{ml})$. The combined organic layers were washed with water, dried over $\mathrm{MgSO}_{4}$ and evaporated. The product was purified via recrystallization from petroleum ether.

\subsubsection{3-[3-Methyl-1-phenyl-pyrazolin-5-imine]pyrazino(1,2-a) Pyridine (quinoline)-zero-4-[4(1)] Methine Cyanine Dyes (5a, b)}

Fusion of $3 \mathrm{a}, \mathrm{b}$ with piperidine for about an hour then dissolved the reaction mixture in ethanol and reflux for 3 hours. The reaction mixture concentrated to half of its volume, cooled and precipitated with ice water then recrystallized from petroleum ether.

\subsubsection{2-[H]-3-[3-Methyl-1-phenyl-pyrazolin-5-imine]pyrazino(1,2-a) Pyridine (Quinoline)-bis-zero-1,4[4(1)] Methine Cyanine Dyes (6a-f)}

Ethanolic solution of dye $5 \mathrm{a}, \mathrm{b}$ (1 mol) and pyridin [quinolin]-2(4)-ium-1-ethiodide salts $(1 \mathrm{~mol})$ in the presence of few drops of piperidine were stirred and refluxed for 5 - 7 hrs. The reaction mixtures were filtrated from unreacted materials. The filtrate concentrated to one third of its volume, cooled and acidified with acetic acid. The precipitated products after dilution with water were separated, filtrated, recrystallized from petroleum ether.

\subsection{UV-Vis Spectra Absorption}

$\mathrm{UV}$-Vis spectra for all dyes in pure and mixed solvents were recorded at $25^{\circ} \mathrm{C}$ in 
a $1 \mathrm{~cm}$ path length quartz cell on a Cary 3 Spectrophotometer. Ethanolic solution of $1 \times 10^{-5} \mathrm{M}$ was prepared, and the absorbance was measured and the extinction coefficient was calculated in each case.

\subsection{Solvatochromic Studies}

The organic solvents were used of spectroscopic grade which purified according to the recommended methods [25]. The electronic absorption spectra of the studied dyes in different organic solvents were recorded within the wavelength (350 - $700 \mathrm{~nm}$ ) on $6405 \mathrm{UV} /$ Visible recording spectrophotometers using $1 \mathrm{~cm}$ cell. The stock solution of the dye was of the order $10^{-3} \mathrm{M}$. Solutions of low molarities used in spectral measurements were obtained by accurate dilution.

\section{Preparation of Working Dye Solutions}

For studying the effect of pure solvents in the UV and visible range: An accurate volume of the stock solution $\left(10^{-3} \mathrm{M}\right.$ in ethanol) of the dyes were diluted to appropriate volume in order to obtain the required concentration. The spectra were recorded immediately after mixing in order to eliminate as much as possible the effect of time. A range of organic solvents was investigated, including water, dimethylformamide (DMF), ethanol, acetone, carbon tetrachloride, chloroform and benzene. Moreover, to study the spectral behavior in mixed solvents in the visible region: An accurate volume of stock solution $\left(10^{-3} \mathrm{M}\right.$ in ethanol) of the dyes were placed in $10 \mathrm{ml}$ measuring flask containing the required volume of ethanol, then completed to the mark with the other solvent.

\section{Results and Discussions}

\subsection{Synthesis and Structural Characterization of Dyes}

\subsubsection{Dye Synthesis}

The synthesis of zero methine (4a, b \& $5 \mathrm{a}, \mathrm{b})$ and bis-zero methine (6a-f) cyanine dyes was started by preparation of 3-methyl-1-phenyl-pyrazolin-4,4-ketomethylene-quinolin-1-ium ethiodide salts (1) according to reference [26] followed by the reaction of an ethanolic solution of (1) with hydroxyl amine in the presence of sodium acetate to afford 3-methyl-1-phenyl-pyrazolin-4,4-ketooximemethylene-pyridine (quinoline)-1-ium ethiodide salt (2). The reaction of an ethanolic solution of (2) with $\mathrm{I}_{2}$ and pyridine (quinoline) and/or 2-methyl-quinoline afforded 1-phenyl-3-methyl-pyrazolin-4-ketooxime- $\alpha$-methylene-bis pyridin (quinoin)-1(4)-di-ium-iodide(ethiodide) salts (2a, b) \& 1-phenyl-3-methylpyrazolino-4-ketooxime- $\alpha$-methylene-N-2-methyl-bis-pyridine (quinoline)-1(4)di-ium-iodide(ethiodide) salts $(\mathbf{3} \mathbf{a}, \mathbf{b})$ respectively. Compounds $(\mathbf{2} \mathbf{a}, \mathbf{b})$ and (3a, b) undergo ring closure involving dehydration reaction in piperidine catalyst to afford 2-[3-methyl-1-phenyl-pyrazolin-5-imine] imidazo(1,2-a)Pyridine (quinoline)-zero-3[4(1)] methine cyanine dyes (4a, b) \& 3-[3-Methyl-1-phenyl-pyrazolin5-imine]pyrazino(1,2-a)Pyridin (quinolin)-zero-4-[4(1)] methine cyanine dyes $(5 \mathbf{a}, \mathbf{b})$ respectively. Finally, dyes $(5 \mathrm{a}, \mathbf{b})$ reacted with pyridin [quinolin]-4(1)ium-1-ethiodide salts in presence of piperidine catalyst to afford 2-[H]-3- 
[3-methyl-1-phenyl-pyrazolin-5-imine]pyrazino(1,2-a)pyridin(quinolin)-bis-zer o-1,4 [4(1)] methine cyanine dyes (6a-f), Scheme 1.

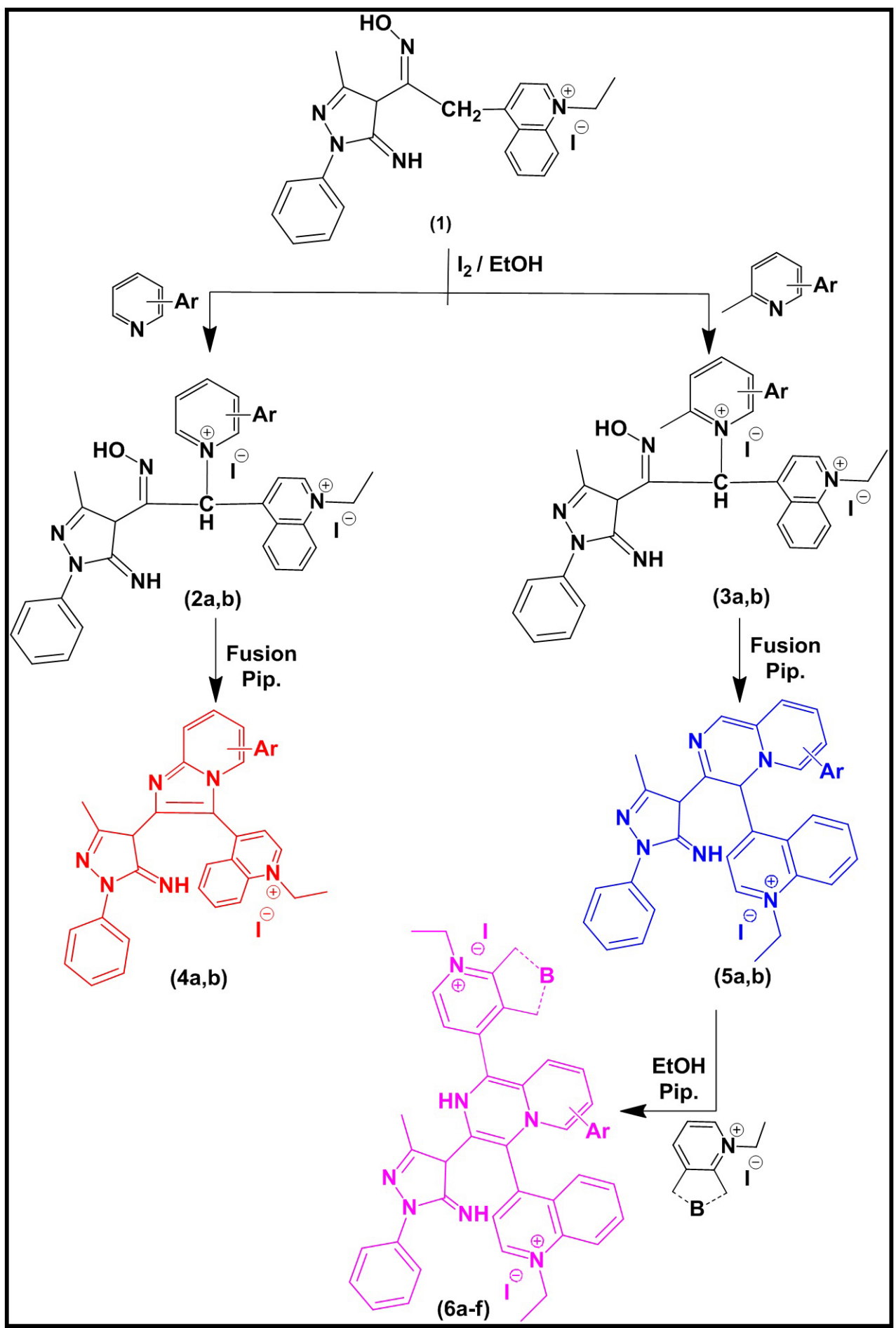

Scheme 1. Synthetic routes of dyes $(4 \mathrm{a}, \mathrm{b}),(5 \mathrm{a}, \mathrm{b})$ and $(6 \mathrm{a}-\mathrm{f})$. Where, $(2, \mathbf{3}, \mathbf{4}, \mathbf{5 a}, \mathbf{b}): \mathrm{Ar}=2,3$ $\operatorname{di}[\mathrm{H}](\mathrm{a}) ; \mathrm{A}=2,3-\mathrm{C}_{4} \mathrm{H}_{4}$ (b); (6a-f): $\mathrm{Ar}=2,3 \mathrm{di}[\mathrm{H}], \mathrm{B}=1$-ethyl pyridin-4-ium salt (a); $\mathrm{A}=2,3$ $\operatorname{di}[\mathrm{H}], \mathrm{B}=1$-ethyl-quinolin-4-ium salt (b); $\mathrm{A}=2,3 \mathrm{di}[\mathrm{H}], \mathrm{B}=2$-ethyl-quinolin-1-ium salt (c); $\mathrm{A}=$ 2, 3- $\mathrm{C}_{4} \mathrm{H}_{4}, \mathrm{~B}=1$-ethyl pyridin-4-ium salt (d); $\mathrm{A}=2$, 3- $\mathrm{C}_{4} \mathrm{H}_{4}, \mathrm{~B}=1$-ethyl-quinolin-4-ium salt (e); $\mathrm{A}$ $=2,3-\mathrm{C}_{4} \mathrm{H}_{4}, \mathrm{~B}=1$-ethyl-quinolin-1-ium salt (f). 


\subsubsection{Structural Characterization}

The structures of $1,2 b, 3 b, 4 b, 5 b \& 6 e$ was characterized \& identified by elemental analysis (Table 1), IR, ${ }^{1} \mathrm{H}-\mathrm{NMR}$ and Mass spectral data. Thus, IR ( $v^{\mathrm{KBr}}$ $\mathrm{cm}^{-1}$ ) showed general absorption bands at $3426.89 \mathrm{~cm}^{-1}$ (OH of oxime), 2963.09 $\mathrm{cm}^{-1}$ (heterocyclic quaternary salt), $1601.59 \mathrm{~cm}^{-1}(\mathrm{C}=\mathrm{C})$ conjugated, 1501.31 $\mathrm{cm}^{-1}(\mathrm{C}=\mathrm{N}), 750.174 \mathrm{~cm}^{-1}$ (Aromatic compound) for $1 ; 3427.85 \mathrm{~cm}^{-1}(\mathrm{OH}$ of oxime), $2926.45 \mathrm{~cm}^{-1}$ (heterocyclic quaternary salt), $1598.7 \mathrm{~cm}^{-1}(\mathrm{C}=\mathrm{C})$ conjugated, $1494.56 \mathrm{~cm}^{-1}(\mathrm{C}=\mathrm{N}), 755.959 \mathrm{~cm}^{-1}$ (Aromatic compound) for $2 \mathrm{~b} ; 3423.99$ $\mathrm{cm}^{-1}$ (OH of oxime), $2966.95 \mathrm{~cm}^{-1}$ (heterocyclic quaternary salt), $1597.73 \mathrm{~cm}^{-1}$ $(\mathrm{C}=\mathrm{C})$ conjugated, $1493.6 \mathrm{~cm}^{-1}(\mathrm{C}=\mathrm{N}), 756.923 \mathrm{~cm}^{-1}$ (Aromatic compound) for $\mathbf{3 b}$. Mass spectra of $\mathbf{1}, \mathbf{2 a}, \mathbf{3 b}, \mathbf{4 a}, \mathbf{5 a}$ and $\mathbf{5 b}$ confirmed a molecular formula agree with a molecular ion peaks at $m / z=515$, and base peak at $m / z=69$ for compound 1 , a molecular ion peaks at $m / z=719$, and base peak at $m / z=77$ for dye 2a, a molecular ion peaks at $m / z=362$, and base peak at $m / z=77$ for dye $3 b$, a molecular ion peaks at $m / z=574$, and base peak at $m / z=69$ for dye $4 a$, a molecular ion peaks at $m / z=435$, and base peak at $m / z=77$ for compound $5 \mathbf{a}$ and a molecular ion peaks at $m / z=635$, and base peaks at $m / z=158 \& 377$ for $5 \mathrm{~b}$. ${ }^{1} \mathrm{H}-\mathrm{NMR}$ (DMSO, $300 \mathrm{MHz}$ ) spectra of showed signals at $\delta 1.01-1.113(\mathrm{~s}, 3 \mathrm{H}$, $\left.\mathrm{CH}_{3}\right)$ and $\left(\mathrm{t}, 3 \mathrm{H}, \mathrm{CH}_{3}\right), 1.89(\mathrm{~s}, \mathrm{H}, \mathrm{CH}), 2.5\left(\mathrm{~s}, 2 \mathrm{H}, \mathrm{CH}_{2}\right), 2.28(\mathrm{~s}, 1 \mathrm{H}, \mathrm{OH}), 3.16-$ $3.76\left(\mathrm{q}, 2 \mathrm{H}, \mathrm{CH}_{2}\right), 6.65-7.199(\mathrm{~m}, 9 \mathrm{H}, \mathrm{Ar}-\mathrm{H}), 7.4-8.2(\mathrm{~m}, 6 \mathrm{H}$, heterocyclic quaternary salt); $\delta 1.3\left(\mathrm{t}, 3 \mathrm{H}, \mathrm{CH}_{3}\right), 1.45(\mathrm{~s}, 1 \mathrm{H}), 2.02\left(\mathrm{~s}, 3 \mathrm{H}, \mathrm{CH}_{3}\right), 2.1(\mathrm{~s}, 1 \mathrm{H}, \mathrm{CH})$, $2.67(\mathrm{~s}, 1 \mathrm{H}, \mathrm{OH}), 2.8(\mathrm{~s}, 1 \mathrm{H}, \mathrm{NH}), 4.3\left(\mathrm{q}, 2 \mathrm{H}, \mathrm{CH}_{2}\right), 6.6-8.4(\mathrm{~m}, 16 \mathrm{H}, \mathrm{Ar})$ for $2 \mathrm{a}$; $\delta 1.43\left(\mathrm{t}, 3 \mathrm{H}, \mathrm{CH}_{3}\right), 1.6(\mathrm{~s}, 1 \mathrm{H}, \mathrm{CH}), 1.92\left(\mathrm{~s}, 3 \mathrm{H}, \mathrm{CH}_{3}\right), 2.9(\mathrm{~s}, 1 \mathrm{H}, \mathrm{NH}), 4.02(\mathrm{q}$, $\left.2 \mathrm{H}, \mathrm{CH}_{2}\right), 6.6-8.8(\mathrm{~m}, 16 \mathrm{H}, \mathrm{Ar})$ for $5 \mathrm{a}$ and $\delta 1.45\left(\mathrm{t}, 6 \mathrm{H}, 2 \mathrm{CH}_{3}\right), 1.6(\mathrm{~s}, 3 \mathrm{H}$, $\left.\mathrm{CH}_{3}\right), 2.27(\mathrm{~s}, 1 \mathrm{H}, \mathrm{CH}), 4.52\left(\mathrm{q}, 4 \mathrm{H}, 2 \mathrm{CH}_{2}\right), 6.7-8.9(\mathrm{~m}, 19 \mathrm{H}, \mathrm{Ar}), 12.6(\mathrm{~s}, 1 \mathrm{H}$, $=\mathrm{NH})$, for $6 \mathrm{a}$.

\subsection{Color, Spectral and Solvatochromic Behaviour}

\subsubsection{Spectral Behavior in EtOH}

2-[3-Methyl-1-phenyl-pyrazolin-5-imine] imidazo(1, 2-a)Pyridin (quinolin)zero-3[4(1)] methine cyanine dyes (4a, b) \& 3-[3-Methyl-1-phenyl-pyrazolin-5imine] pyrazino(1,2-a)Pyridin (quinolin)-zero-4-[4(1)] methine (5a, b) and 2-[H]-3-[3-methyl-1-phenyl-pyrazolin-5-imine] pyrazino (1, 2-a)Pyridine (quinoline)-bis-zero-1,4[4(1)] methine cyanine dyes (6a-f) are highly colored compounds. Their color ranging from (reddish-red), easily (partially) soluble in polar (non) organic solvents exhibiting colored solutions concomitant with slight or intense greenish-red fluorescence depending upon the solvent used. They are soluble in concentrated $\mathrm{H}_{2} \mathrm{SO}_{4}$ acid liberating iodine vapour on warming. Their ethanolic solutions gave permanent colours in basic media which reversibly discharged on acidification. Thus, the visible absorb-maximum of dye $4 \mathrm{a}[\mathrm{A}=\mathrm{py}-$ ridin-4-ium salt] showed $\left(\lambda_{\max }=470 \mathrm{~nm} ; \varepsilon_{\max }=1092 \mathrm{M}^{-1} \mathrm{~cm}^{-1}\right)$. Substitution of [A = pyridin-4-ium salt $]$ in dye $4 \mathrm{a}$ by $[\mathrm{A}=$ quinolin-4-ium salt $]$ in $4 \mathrm{~b}$ exhibit $\left(\lambda_{\max }=492 \mathrm{~nm} ; \varepsilon_{\max }=1397 \mathrm{M}^{-1} \mathrm{~cm}^{-1}\right)$ resulted in bathochromic shift of $\Delta \lambda_{\max }=22$ $\mathrm{nm}$. This is due to the more extensive $\pi$-delocalization and extra conjugation in 
the quinoline ring. Moreover, the visible absorb-maximum of $5 \mathrm{a}$ [A $=$ pyridin-4-ium salt] showed $\left(\lambda_{\max }=460 \mathrm{~nm} ; \varepsilon_{\max }=698 \mathrm{M}^{-1} \mathrm{~cm}^{-1}\right)$. Substitution of [A = pyridin-4-ium salt] in dye $5 \mathrm{a}$ by [A $=$ quinolin- 4 -ium salt] in dye $5 \mathrm{~b}$ exhibit $\left(\lambda_{\max }\right.$ $=498 \mathrm{~nm} ; \varepsilon_{\max }=1010 \mathrm{M}^{-1} \mathrm{~cm}^{-1}$ ) resulted in bathochromic shift of $\Delta \lambda_{\max }=38 \mathrm{~nm}$. This is due to the more extensive $\pi$-delocalization and extra conjugation in the quinoline ring. Finally, dye $6 \mathrm{a}[\mathrm{A}=2,3 \mathrm{di}[\mathrm{H}], \mathrm{B}=1$-ethyl pyridin-4-ium salt $]$ showed $\left(\lambda_{\max }=390 \& 520 \mathrm{~nm} ; \varepsilon_{\max }=2700 \& 2443 \mathrm{M}^{-1} \mathrm{~cm}^{-1}\right)$. Substitution of [A $=\mathrm{A}=2,3 \mathrm{di}[\mathrm{H}], \mathrm{B}=1$-ethyl pyridin-4-ium salt $]$ in dye $6 \mathbf{a}$ by $[\mathrm{A}=2,3 \mathrm{di}[\mathrm{H}], \mathrm{B}$ $=1$-ethyl-quinolin-4-ium salt $]$ in dye $6 \mathrm{~b}$ exhibit $\left(\lambda_{\max }=480 \mathrm{~nm} ; \mathcal{E}_{\max }=670 \mathrm{M}^{-1}\right.$ $\mathrm{cm}^{-1}$ ) resulted in bathochromic shift of $\Delta \lambda_{\max }=40 \mathrm{~nm}$. This is due to the more extensive $\pi$-delocalization and extra conjugation in the quinoline ring. Substitution of $[\mathrm{A}=2,3 \mathrm{di}[\mathrm{H}], \mathrm{B}=1$-ethyl pyridin-4-ium salt] in dye $6 \mathrm{a}$ by $[\mathrm{A}=2,3$ $\operatorname{di}[\mathrm{H}], \mathrm{B}=1$-ethyl-quinolin-4-ium salt $]$ in dye $6 \mathrm{c}$ exhibit $\left(\lambda_{\max }=500 \mathrm{~nm} ; \varepsilon_{\max }=\right.$ $\left.1780 \mathrm{M}^{-1} \mathrm{~cm}^{-1}\right)$. Substitution of $[\mathrm{A}=2,3 \mathrm{di}[\mathrm{H}], \mathrm{B}=1$-ethyl-quinolin-4-ium salt $]$ in dye $6 \mathrm{c}$ by $\left[\mathrm{A}=2,3-\mathrm{C}_{4} \mathrm{H}_{4}, \mathrm{~B}=1\right.$-ethyl pyridin-4-ium salt] in dye $6 \mathrm{~d}$ exhibit $\left(\lambda_{\max }\right.$ $\left.=475 \mathrm{~nm} ; \varepsilon_{\max }=612 \mathrm{M}^{-1} \mathrm{~cm}^{-1}\right)$ resulted in hypsochromic shift of $\Delta \lambda_{\max }=25 \mathrm{~nm}$. This is due to the less extensive $\pi$-delocalization and less conjugation in the quinoline ring. Substitution of $\left[\mathrm{A}=2,3-\mathrm{C}_{4} \mathrm{H}_{4}, \mathrm{~B}=1\right.$-ethyl pyridin-4-ium salt $]$ in dye $6 \mathrm{~d}$ by $\left[\mathrm{A}=2,3-\mathrm{C}_{4} \mathrm{H}_{4}, \mathrm{~B}=1\right.$-ethyl-quinolin-4-ium salt $]$ in dye $6 \mathrm{e}$ exhibit $\left(\lambda_{\max }=478\right.$ $\mathrm{nm} ; \varepsilon_{\max }=1593 \mathrm{M}^{-1} \mathrm{~cm}^{-1}$ ) resulted in hypsochromic shift of $\Delta \lambda_{\max }=3 \mathrm{~nm}$. This is due to the more extensive $\pi$-delocalization and extensive conjugation in the quinoline ring. Substitution of $\left[\mathrm{A}=2,3-\mathrm{C}_{4} \mathrm{H}_{4}, \mathrm{~B}=1\right.$-ethyl-quinolin-4-ium salt $]$ in dye 6e by $\left[\mathrm{A}=2,3-\mathrm{C}_{4} \mathrm{H}_{4}, \mathrm{~B}=\right.$-ethyl-quinolin-1-ium salt $]$ in dye $\mathbf{6 f}$ exhibit $\left(\lambda_{\max }=474\right.$

$\mathrm{nm} ; \varepsilon_{\max }=1012 \mathrm{M}^{-1} \mathrm{~cm}^{-1}$ ) resulted in hypsochromic shift of $\Delta \lambda_{\max }=4 \mathrm{~nm}$. This is due to the less extensive $\pi$-delocalization and less conjugation in the isoquinoline ring. Comparison of dyes $(4 a, b)$ and $(5 a, b)$, Observed that dyes $(4 a, b)$ giving higher values of $\lambda_{\max }$ than dyes $(5 \mathbf{a}, \mathbf{b})$ this can be explained from the extending of $\pi$-delocalization through three rings in case of dyes $(4 a, b)$. Moreover 3-Methyl-1-phenyl-pyrazolin-5-imine-4-pyrazino(1,2-a) Pyridine (quinoline)bis-zero-2,5[4(1)]methine cyanine dyes (6a-f) are bathochromic shift to 3-Methyl-1-phenyl-pyrazolin-5-imine-4-pyrazino(1,2-a) Pyridine (quinoline)zero-2[4(1)] methine cyanine dyes $(5 \mathbf{a}, \mathbf{b})$ this back to extend of $\pi$-delocalization in case of bis zero methine cyanine dyes (6a-f).

\subsubsection{Solvatochromism}

The color changes of cyanine dyes with solvents (solvatochromism) was previously discussed by [27] and extended [28] to correlate the effect of structure on molecular orbital energy levels. It is clear that the type of substituents and the solvent polarity change the electron densities of cyanine dyes. The visible absorption spectra of dyes $5 \mathrm{~b}$ and $6 \mathrm{e}$ in the wavelength range $400-700 \mathrm{~nm}$ have been studied in different organic solvents $\left(\mathrm{H}_{2} \mathrm{O}, \mathrm{DMF}, \mathrm{EtOH}\right.$, acetone, $\mathrm{CCl}_{4}, \mathrm{CHCl}_{3}$, \& $\mathrm{C}_{6} \mathrm{H}_{6}$ ) respectively [29] as shown in (Figure 1). This is constructed with the intention to illustrate the solvatochromic behavior of these dyes, $\left(\lambda_{\max }\right.$ and $\left.\varepsilon_{\max }\right)$ values of the intramolecular charge transfer bands are given in (Table 2). These 

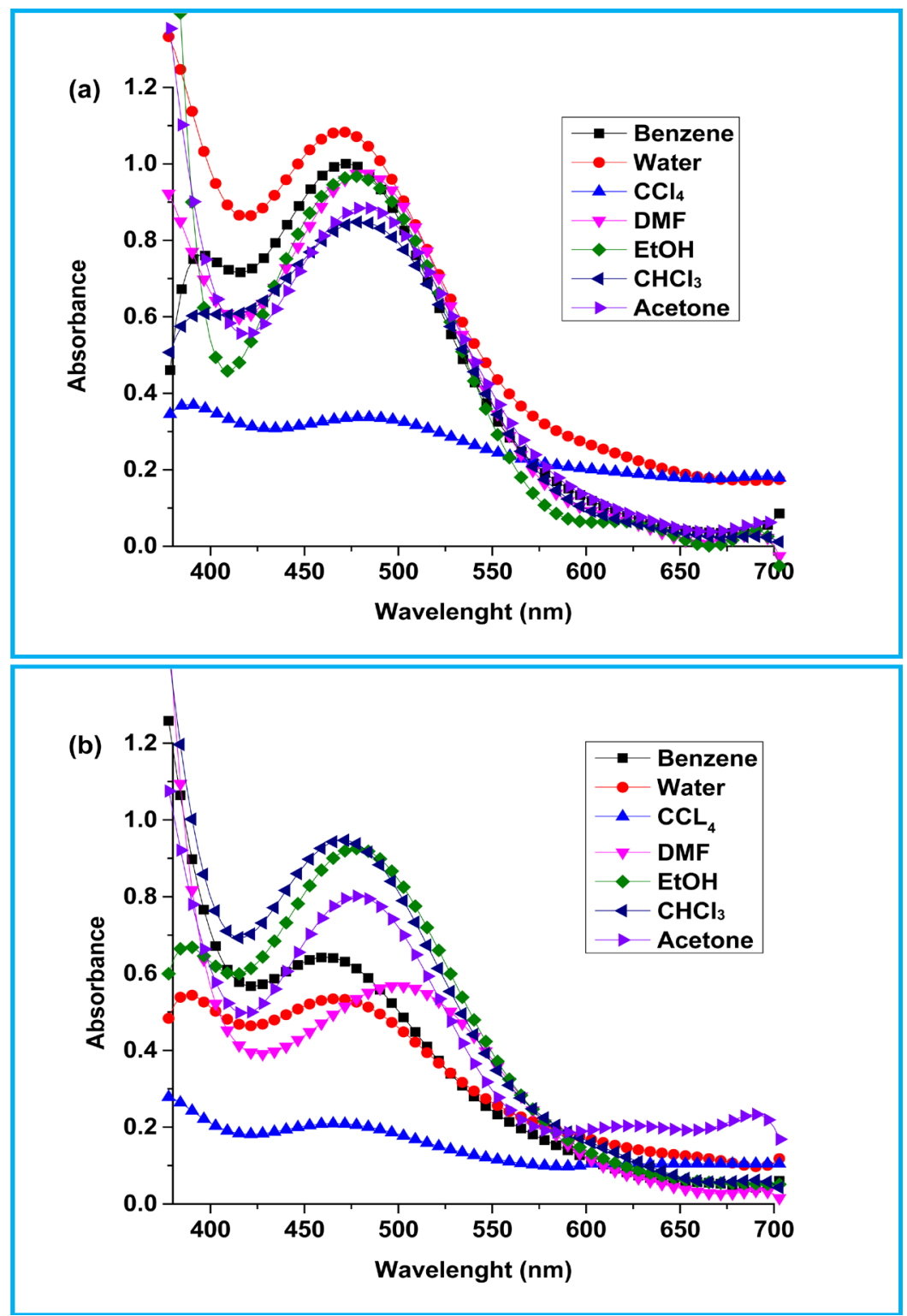

Figure 1. (a) (b) Vis. spectra of (5b) and (6e) respectively in pure organic solvents.

Table 2. Values of absorption ( $\mathrm{nm})$ and extinction coefficients $\left(\mathrm{M}^{-1} \mathrm{~cm}^{-1}\right)$ of dyes $(5 \mathbf{b}$ and $6 \mathrm{e}$ ) in pure organic solvents.

\begin{tabular}{ccccc}
\hline & \multicolumn{3}{c}{ 5b } & \multicolumn{2}{c}{$6 \mathrm{e}$} \\
\cline { 2 - 5 } Solvent & $\lambda_{\max }$ & $\varepsilon_{\max }$ & $\lambda_{\max }$ & $\varepsilon_{\max }$ \\
\hline $\mathrm{C}_{6} \mathrm{H}_{6}$ & 470 & 984.7 & 462 & 642.03 \\
Water & 474 & 669.9 & 469 & 534.2 \\
$\mathrm{CCl}_{4}$ & 449 & 647.9 & 465 & 220 \\
$\mathrm{DMF}$ & 501 & 869.49 & 500 & 568 \\
$\mathrm{EtOH}$ & 498 & 918.86 & 478 & 925.5 \\
$\mathrm{CHCl}_{3}$ & 470 & 977.42 & 472 & 947 \\
$\mathrm{Acetone}$ & 492 & 771.46 & 478 & 802 \\
\hline
\end{tabular}


dyes are showed positive solvatochromism with increased solvent polarity, which depend on the structure and the type of dye. This indicates that the polar excited states of these cyanine dyes are stabilized by polarization interaction forces as the polarizability of the solvent is increased. This behaviour occurs as a result of electrostatic interactions of the distributed cationic charges with the dipoles of the solvated molecules which lead to formation of specific solvated forms of dyes. The absorption spectra of the dyes in ethanol are characterized by the presence of one or two essential bands which reflects the presence of intermolecular charge transfer. This intermolecular charge transfer had arisen from transferring the electron lone pair of the nitrogen atoms of the heterocyclic ring system towards the positively charged residue along the conjugated chain between both. The representing graphs disclosed that these electronic charge transfer bands exhibit a hypsochromic shifts in ethanol relative to $\mathrm{DMF}, \mathrm{CHCl}_{3}$, and $\mathrm{CCl}_{4}$. This shift can be attributed to the following factors: The bathochromic shift occurred in DMF relative to ethanol is mainly a result of the increase in solvent polarity due to increasing the dielectric constant of the former. The hypsochromic shifts appeared in ethanol relative to $\mathrm{CHCl}_{3} \& \mathrm{CCl}_{4}$ is generated from the solute-solvent interaction through intermolecular hydrogen bonding between ethanol and the lone pair of electrons within the heterocyclic ring system. Otherwise, this decreases the mobility of the electron cloud over the conjugated pathway towards the positively charged center. It was worth mentioning that the intermolecular hydrogen bonding between $\mathrm{CHCl}_{3}$ molecules and the lone pair of electrons of nitrogen atoms of the heterocyclic ring system is difficult due to the steric hindrance of the three bulk chlorines. Moreover, the solute solvent interactions in cases of $\mathrm{CHCl}_{3} \& \mathrm{CCl}_{4}$ generated a residual negative charge on the nitrogen atoms of the heterocyclic ring system which intern facilitated the electronic charge transfer to the positively charged center and this explain the bathochromic shifts in these solvents relative to ethanol. The unexpected hypsochromic shifts in the absorption spectral maxima in water relative to ethanol and its lower extinction coefficients were mainly ascribed to the ease of interactions of water molecules, through intermolecular hydrogen bonding, with the lone pair of electrons of the nitrogen atoms of the heterocyclic ring system, through intermolecular hydrogen bonding, which intern preclude the charge transfer from the heterocyclic ring system to the positively charged residue along the conjugated bridge.

\subsubsection{Absorption Spectra in Mixed Solvent}

The absorption spectra of dye (6e) in $1 \times 10^{-4} \mathrm{M} \mathrm{DMF}$ in the presence of different concentrations of benzene are shown in (Figure 2).

It was obvious that in presence of $12.97 \mathrm{M}$ of DMF, the spectrum exhibits a band located at $500 \mathrm{~nm}$. In the presence of $1.16 \mathrm{M}$ of DMF, the band is shifted to $463 \mathrm{~nm}$ concomitant with a gradual blue shift. Also, an increase in band intensity at fixed wavelength $(500 \mathrm{~nm})$ is observed on increasing of $\mathrm{C}_{6} \mathrm{H}_{6}$ concentration as depicted in (Figure 3(a)). The increase in absorbance as well as the gradual 


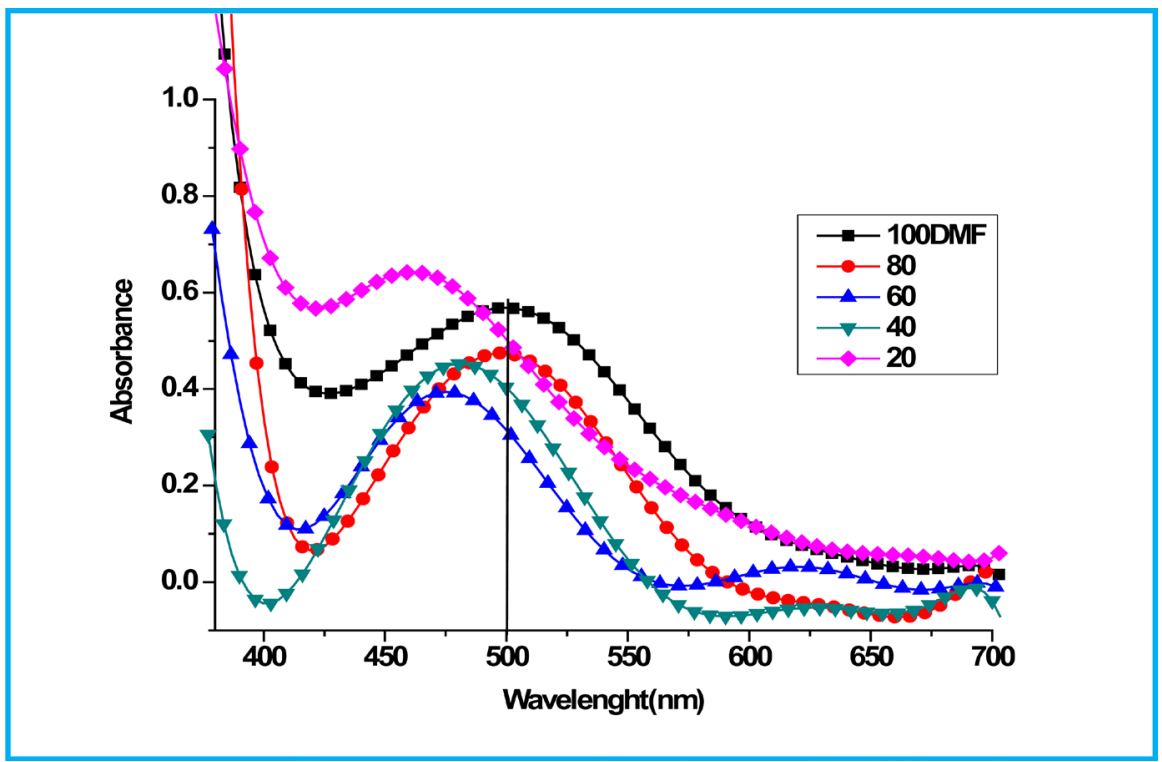

Figure 2. Absorption spectra of dye $6 \mathrm{e}$ in DMF- $\mathrm{C}_{6} \mathrm{H}_{6}$ mixed solvents.

blue shift in the maximum absorption wavelength on increasing the $\mathrm{C}_{6} \mathrm{H}_{6}$, content can be described to the gradual formation of the complex species through intermolecular hydrogen-bond. The graphical representation of absorbance at $500 \mathrm{~nm}$ against the mole fraction of DMF (Figure 3(b)), reveals that the absorbance increases gradually with increasing mole fraction. on plotting versus $(D-1 / D+1)$ ( $D$ is dielectric constant of the solvent added) versus the band shift $(\Delta v)$, a straight line is obtained which at $5.19 \mathrm{M}$ DMF give another straight-line (Figure 3(d)). Furthermore, a broken line is obtained on plotting the absorbance against the dielectric constant of the medium (Figure 3(c)). Such behaviour indicates that factors other than the change in the dielectric constant of the medium are responsible for the shift of $\lambda_{\max }$ at lower and higher percentage of DMF. These factors mainly include the solute-solvent interaction through intermolecular hydrogen bond which leads to the formation of some molecular complex. On plotting the excitation energy (E) versus the mole fraction of ethanol (Figure 3(e)), a broken line with three segments is obtained. The first segment represents the orientation energy of the solvent molecules around the solute. The second segment corresponds to the molecule complex formation, where the third one represents the steady state of energy attained after complete formation of the molecular complex. From the above relations, it is clear that the position of the bands and consequently the excitation energy depends not only on the mole fraction of ethanol, but also on the following: 1) Solvation energy. 2) Orientation of solvent molecules around the solute molecule in the ground states. 3) Dipole moment of the solute in both ground and excited states. 4) Dipole-dipole interaction between solute and solvents. 5) The strength of $\mathrm{H}$-bond between solute and solvent in both ground and excited states. In pure DMF solution, the dye molecule form solvent cage, which is affected on adding $\mathrm{C}_{6} \mathrm{H}_{6}$. At lower $\mathrm{C}_{6} \mathrm{H}_{6}$ content, DMF molecules will distribute themselves uniformly on all 

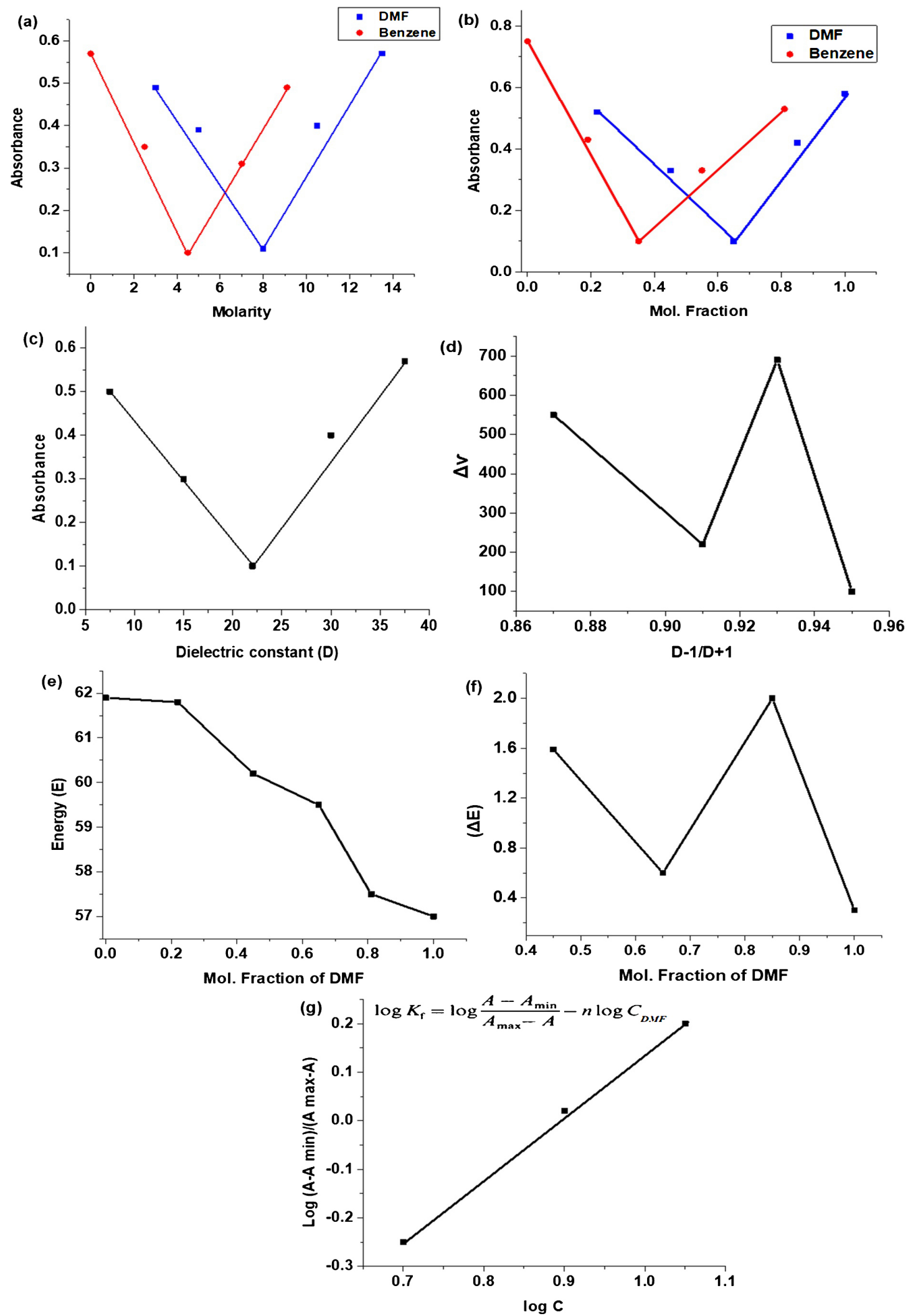

Figure 3. Relation between (a) Absorbance and molarity; (b) mole fraction (b) for dye 6e in DMF- $\mathrm{C}_{6} \mathrm{H}_{6}$ mixed solvents; Relation between (c) absorbance and D of the medium; (d) $\Delta v$ and $D-1 / D+1$; Relation between (e) the mole fraction of DMF and E; (f) the mole fraction and $\Delta \mathrm{E}$; (g) Relation between $\log \left(A-A_{\min }\right) /\left(A_{\max }-A\right)$ and $\log \mathrm{C}$. 
the solvation sheaths around the molecules. The added molecules may first enter the outer solvation sheaths and then will introduce themselves in the first sheaths as their proportions are increased. This is probably due to the fact that addition of DMF permits the formation of a solvent cage around the solute molecules, through intermolecular hydrogen-bonding as shown in (Table 3 ) it is possible to evaluate the excitation energy of the solute in pure $\mathrm{C}_{6} \mathrm{H}_{6}$ is equal to $61.9 \mathrm{~K} \mathrm{Cal} \mathrm{mol}^{-1}$ whereas the value in pure DMF amounts to $57.2 \mathrm{~K} \mathrm{Cal} \mathrm{mol}^{-1}$. The difference between the excitation energy in pure DMF (Figure 3(f)) and the first inflection point is called orientation energy of the solvent molecules around the solute molecules and equal to $3 \mathrm{~K} \mathrm{Cal} \mathrm{mol}^{-1}$. While, the difference between the excitation energy in pure DMF and the second inflection point is called $\mathrm{H}$-bond energy and equal to $2.3 \mathrm{~K} \mathrm{Cal} \mathrm{mol}^{-1}$. The value of the stability constant $\left(\mathrm{K}_{\mathrm{f}}\right)$ of the complex with $\mathrm{C}_{6} \mathrm{H}_{6}$ was determined from the spectral behaviour in mixed solvents at fixed $\lambda_{\max }=500 \mathrm{~nm}$ using the relations described in (Figure $3(\mathrm{~g}))$ From this figure, it is observed that $\log K_{f}$ is 1.464 , and thus $K_{f}$ is equal to 29.1. Finally, the values of $\Delta \mathrm{G}$ (free energy change of formation) can be calculated from Gibbs Equation (1)

$$
-\Delta G=R T \ln K_{f}
$$

where $R$ is the constant of ideal gas, $T$ is the absolute temperature and $\ln K_{f}$ calculated from $\log K_{f}\left(\log K_{f}=1.464 ; K_{f}=29.1\right)$, and the calculation gives $-\Delta G=$ $0.345 \mathrm{~K} \mathrm{cal} \mathrm{mol}^{-1}$. The number of $\mathrm{C}_{6} \mathrm{H}_{6}$ molecules $(n)$ complexed with the solute is computed from (Figure $3(\mathrm{~g})$ ); the value of $n$ was found to be 1 indicate that 1:1 complex is formed. The value of $K_{f}$ is dependent on both solute and solvent used.

\section{Conclusion}

Highly stable series of novel zero/Bis zero methine cyanine dyes stabilized by $\mathrm{C}-\mathrm{N}$ bond were synthesized based on N-Bridge head heterocyclic compounds. The stability of dye formation is due to that N-bridge head heterocyclic compounds used as precursors possess high site reactivity susceptible to be attacked by either Electrophile/Nucleophile in the substitution/addition reactions. The absorption spectra of the synthesized dyes were investigated in different organic solvents and a mixed solvent system. The results indicated that the colour of these dyes depends on the length of conjugation within the structure. Dyes having unsaturated terminal groups are more bathochromic than those with saturated terminal groups. The absorption spectra of these dyes in different organic

Table 3. Commutative data obtained for dye $6 \mathrm{e}$ in mixed solvents. Where $\mathrm{N}$ : Number of hydrogen bonding.

\begin{tabular}{|c|c|c|c|c|c|c|c|c|c|c|}
\hline Dye & Solvent System & $\begin{array}{r}\text { Excita } \\
\text { K } \\
\text { Pur }\end{array}$ & $\begin{array}{l}\text { n energy } \\
\mathrm{mol}^{-1} \\
\text { olvents }\end{array}$ & $\begin{array}{c}\text { Orient energy } \\
\mathrm{K} \mathrm{Cal} \mathrm{mol}^{-1}\end{array}$ & $\begin{array}{c}\text { H-bond } \\
\text { energy } \\
\mathrm{K} \mathrm{Cal} \mathrm{mol}^{-1}\end{array}$ & $\begin{array}{c}\text { Total } \\
\text { energy } \\
\mathrm{K} \mathrm{Cal} \mathrm{mol}^{-1}\end{array}$ & $\mathrm{~N}$ & $\begin{array}{c}\log K_{f} \\
(-)\end{array}$ & $\begin{array}{l}\mathrm{K}_{\mathrm{f}} \\
(-)\end{array}$ & $\begin{array}{c}\Delta \mathrm{G} \\
\mathrm{K} \mathrm{Cal} \mathrm{mol}^{-1} \\
( \pm)\end{array}$ \\
\hline $6 e$ & (DMF-Benzene) & $\begin{array}{c}57.2 \\
(\mathrm{DMF})\end{array}$ & $\begin{array}{c}61.9 \\
\text { (Benzene) }\end{array}$ & 3 & 2.3 & 5.2 & 2 & 1.464 & 29.1 & 0.3454 \\
\hline
\end{tabular}


solvents undergo bathochromic or hypsochromic shift depending on the structure of dye and the type of solvent. The results of spectral behaviour in a mixed solvent system indicate the formation of a hydrogen bonding between the solute and solvent molecules and allow the measurement of certain energies, such as hydrogen-bonding, orientation and free energy.

\section{Conflicts of Interest}

The authors declare no conflicts of interest regarding the publication of this paper.

\section{References}

[1] Gandorfer, A., Rohleder, M., Charteris, D.G., Sethi, C., Kampik, A. and Luthert, P. (2005) Staining and Peeling of the Internal Limiting Membrane in the Cat Eye. Current Eye Research, 30, 977-987. https://doi.org/10.1080/02713680500320745

[2] Gerding, H., Timmermann, M. and Thelen, U. (2011) Intravital Staining of the Internal Limiting Membrane with a Novel Heavy Solution of Brilliant Blue G. Klinische Monatsblatter Fur Augenheilkunde, 228, 298-301. https://doi.org/10.1055/s-0031-1273213

[3] Lin, Y.Y., Liu, J.H. and Chang, Y. (2018) Foetal Bovine Serum Can Reduce Toxicity of Indocyanine Green, Brilliant Blue G and Trypan Blue in ARPE-19 Cellular Model That Suggests New Surgical Staining Protocols for Internal Limiting Membrane Peeling Procedure. Clinical and Experimental Ophthalmology, Online.

[4] Lv, Q., Yang, X., Wang, M., Yang, J., Qin, Z., Kan, Q., et al. (2018) Mitochondria-Targeted Prostate Cancer Therapy Using a Near-Infrared Fluorescence Dye-Monoamine Oxidase A Inhibitor Conjugate. Journal of Controlled Release, 279, 234-242. https://doi.org/10.1016/j.jconrel.2018.04.038

[5] Udayan, S., Sebastian, M., Vijesh, K.R., Nampoori, V.P.N. and Thomas, S. (2018) Thermal Diffusivity and Lifetime Studies of Styryl 7 Dye on DNA-CTMA Complex. Journal of Luminescence, 194, 428-432. https://doi.org/10.1016/j.jlumin.2017.10.065

[6] Zhang, Y., Ning, X., Mao, G., Ji, X. and He, Z. (2018) Fluorescence Turn-On Detection of Target Sequence DNA Based on Silicon Nanodot-Mediated Quenching. Analytical and Bioanalytical Chemistry, 410, 3209-3216. https://doi.org/10.1007/s00216-018-1030-x

[7] An, H.W. and Wang, M.D. (2018) The Self-Assembly of Cyanine Dyes for Biomedical Application In Vivo. In: Wang, H. and Li, L.L., Eds., In Vivo Self-Assembly Nanotechnology for Biomedical Applications, Nanomedicine and Nanotoxicology, Springer, Singapore, 31-55. https://doi.org/10.1007/978-981-10-6913-0_2

[8] Zhu, X., Yuan, L., Hu, X., Zhang, L., Liang, Y., He, S., et al. (2018) Construction of a Fluorine Substituted Chromenylium-Cyanine Near-Infrared Fluorophore for Ratiometric Sensing. Sensors and Actuators B: Chemical, 259, 219-225. https://doi.org/10.1016/j.snb.2017.12.008

[9] Cao, W. and Sletten, E.M. (2018) Fluorescent Cyanine Dye J-Aggregates in the Fluorous Phase. Journal of the American Chemical Society, 140, 2727-2730. https://doi.org/10.1021/jacs.7b11925

[10] Kim, S.H., Han, S.K., Kim, J.J., Lim, W.T., Heo, N.H. and Koh, K.N. (1998) Crystal Structure of a Photoconductive Dithiosquarylium Dye: 2,4-Bis(1,3,3-trimethyl- 
2-indolinylidenemethyl) Cyclobutenediylium-1,3-Dithiolate. Dye Pigment, 39, 259-266. https://doi.org/10.1016/S0143-7208(98)00012-6

[11] Shiring, S.B., Gieseking, R.L., Risko, C. and Brédas, J.L. (2017) Assessment of Front-Substituted Zwitterionic Cyanine Polymethines for All-Optical Switching Applications. The Journal of Physical Chemistry C, 121, 14166-14175. https://doi.org/10.1021/acs.jpcc.7b03471

[12] Pepe, G., Cole, J.M., Waddell, P.G. and McKechnie, S. (2016) Molecular Engineering of Cyanine Dyes to Design a Panchromatic Response in Co-Sensitized Dye-Sensitized Solar Cells. Molecular Systems Design \& Engineering, 1, 86-98. https://doi.org/10.1039/C6ME00014B

[13] Abd El-Aal, R.M., Saber, N.M., Mina, S.M. and Essam, Z.M. (2017) Synthesis and Physicochemical Studies of Some New Quinolinoxazine Pentamethine Cyanine Dyes. Arabian Journal of Chemistry, 10, 82-90. https://doi.org/10.1016/j.arabjc.2012.06.003

[14] Khlebnikov, A.F., Golovkina, M.V., Novikov, M.S. and Yufit, D.S. (2012) A Novel Strategy for the Synthesis of 3-(N-Heteryl)pyrrole Derivatives. Organic Letters, 14, 3768-3771. https://doi.org/10.1021/ol3016594

[15] Huang, S., Yang, C., Huang, J., Wang, X. and Wang, M. (2018) Near-Infrared Fluorescent Pyrrolopyrrole Cyanine Derivatives and Colloidal Nanoparticles with Tunable Optical Properties for In Vivo Bioimaging. Dye Pigment, 154, 269-274. https://doi.org/10.1016/j.dyepig.2018.02.029

[16] Li, B., Lu, L., Zhao, M., Lei, Z. and Zhang, F. (2018) An Efficient 1064 nm NIR-II Excitation Fluorescent Molecular Dye for Deep-Tissue High-Resolution Dynamic Bioimaging. Angewandte Chemie International Edition, 57, 7483-7487.

[17] Heaney, F., McCarthy, T., Mahon, M. and McKee, V. (2005) Bridgehead Nitrogen Heterocycles Which Contain the Quinazoline Moiety-Synthesis and Cycloaddition of 1,2-Dihydroquinazoline 3-Oxides. Organic \& Biomolecular Chemistry, 3, 4351-4361. https://doi.org/10.1039/b511998g

[18] Abengózar, A., Abarca, B., Cuadro, A.M., Sucunza, D., Álvarez-Builla, J. and Vaquero, J.J. (2015) Azonia Aromatic Cations by Ring-Closing Metathesis: Synthesis of Azaquinolizinium Cations. European Journal of Organic Chemistry, 2015, 4214-4223. https://doi.org/10.1002/ejoc.201500404

[19] Aliyeu, T.M., Berdnikova, D.V., Fedorova, O.A., Gulakova, E.N., Stremmel, C. and Ihmels, H. (2016) Regiospecific Photocyclization of Mono- and Bis-Styryl-Substituted N-Heterocycles: A Synthesis of DNA-Binding Benzo[c]quinolizinium Derivatives. The Journal of Organic Chemistry, 81, 9075-9085. https://doi.org/10.1021/acs.joc.6b01695

[20] Zhang, G., Yang, L., Wang, Y., Xie, Y. and Huang, H. (2013) An Efficient Rh/O $\mathrm{O}_{2}$ Catalytic System for Oxidative C-H Activation/Annulation: Evidence for $\mathrm{Rh}(\mathrm{I})$ to $\mathrm{Rh}$ (III) Oxidation by Molecular Oxygen. Journal of the American Chemical Society, 135, 8850-8853. https://doi.org/10.1021/ja404414q

[21] Abd El-Aal, R.M., Koraiem, A.I.M. and El-Deen, N.M.S. (2005) Synthesis and Characterisation of Monomethine Cyanine Dyes Based on N-Bridgehead Heterocycles. Coloration Technology, 121, 228-236. https://doi.org/10.1111/j.1478-4408.2005.tb00278.x

[22] Koraiem, A.I., El-Shafie, A.M., Abdellah, I.M., Abdelatif, F.F. and Abdelaal, R.M. (2018) Microwave Assisted Synthesis and Solvato (Media)-Chromic Behaviour of Some New Series Photosensitizing Dyes. Journal of Applicable Chemistry, 7, 309-324. 
[23] Koraiem, A.I.M., Abd El-Aal, R.M. and Salah El-Deen, N.M. (2006) The Use of N-Bridgehead Heterocyclic Indolizinium Ylide in the Synthesis of Aza-Cyanine Dyes. Dye Pigment, 68, 235-242. https://doi.org/10.1016/j.dyepig.2005.01.007

[24] Koraiem, A.I., El-Shafie, A.M. and Abdellah, I.M. (2018) Synthesis and Physicochemical Properties of Novel Zero Methine Cyanine Dyes Based on N-Bridgehead Indolizine (Benzoindolizine) Heterocycles. IJARSET, 5, 5711-5721.

[25] Riddick, J.A., Bunger, W.B. and Sakano, T.K. (1986) Organic Solvents: Physical Properties and Methods of Purification (Techniques of Chemistry). 4th Edition, Wiley Intercedence, Hoboken.

[26] Abd El-Motaleb, A.M. (2002) Synthesis and Photophysical Properties of Novel Cyanine Dyes. M.Sc. Dissertation, Faculty of Science South Valley University, Aswan.

[27] Gibson, H.W. and Bailey, F.C. (1975) Linear Free Energy Relationships. IV. Synthesis and Spectral Characterization of Some New Solvatochromics. N-( $p$-Substituted) benzyl-2'-hydroxy-4-stilbazolium Betaines. Canadian Journal of Chemistry, 53, 2162-2170. https://doi.org/10.1139/v75-301

[28] Abu El-Hamd, R.M. (1997) Some New Fused Heterocyclic Cyanine Dyes with Ring Junction Heteroatom. Chemical Papers, 51, 117-127.

[29] Weast, R.C. and Astl, M.J. (1980-1981) CRC Handbook of Chemistry and Physics. 61st Edition, CRC Press, Inc., Boca Raton. 